\title{
PASAR MODAL YANG EFISIEN
}

\author{
I Nyoman Sujana \\ Jurusan Pendidikan Ekonomi \\ Universitas Pendidikan Ganesha \\ Singaraja, Indonesia \\ e-mail: sujanatbn@yahoo.com
}

\begin{abstract}
Abstrak
Pasar modal sebagai pasar untuk berbagai instrumen keuangan jangka panjang yang bisa diperjualbelikan, baik dalam bentuk hutang ataupun modal sendiri, baik yang diterbitkan oleh pemerintah, public authorities, maupun perusahaan swasta. Dengan adanya pasar modal, para pemodal dimungkinkan untuk melakukan disversifikasi investasi, membentuk portofolio sesuai dengan risiko yang mereka bersedia tanggung dan tingkat keuntungan yang mereka harapkan. Dalam keadaan pasar modal yang efisien, hubungan yang positif antara resiko dan keuntungan yang diharapkan akan terjadi. Pasar modal yang efisien adalah pasar modal yang harga sekuritassekuritasnya mencerminkan semua informasi yang relevan. Syarat-syarat yang harus dipenuhi untuk pasar modal yang efisien adalah : (1) diselousure; (2) pasar dalam keadaan seimbang; dan (3) kondisi pasar berlangsung secara bebas. Bentuk-bentuk pasar modal yang efisien meliputi : (1) efisiensi bentuk lemah; (2) efisiensi bentuk setengah kuat; dan (3) efisiensi bentuk kuat. Pengujian pasar modal yang efisien adalah : (1) efisiensi bentuk lemah dengan pengujian koefisien korelasi perubahan harga saham untuk time lag tertentu; (2) efisiensi bentuk setengah kuat dengan pengujian market model (single index model) dan Capital Assets Pricing Model (CAPM); dan (3) efisiensi bentuk kuat dengan pengujian Capital Assets Pricing Model (CAPM) juga yaitu dengan cara menganalisa prestasi berbagai portofolio yang dikelola secara profesional seperti mutual funds.
\end{abstract}

Kata kunci: Pasar modal yang efisien (bentuk lemah, bentuk setengah kuat, bentuk kuat)

\begin{abstract}
Capital market as the market for a variety of long-term financial instruments that can be bought and sold, either in the form of debt or equity, whether issued by governments, public authorities, as well as private companies. With the stock market, investors may be possible to do disversifikasi investment, portfolio formed in accordance with the risks they are willing to bear and the level of profits they expected. In an efficient capital market, a positive relationship between risks and benefits that are expected to occur. Efficient capital markets is that capital market securities, securities prices reflect all relevant information. Conditions that must be met for efficient capital markets are: (1) diselousure, (2) market in a state of balance, and (3) market conditions are free. The forms of efficient capital markets include: (1) weak form efficiency, (2) half-strong form efficiency, and (3) efficiency and strong form. Testing efficient capital markets are: (1) weak form efficiency by testing the correlation coefficient for stock price changes certain time lag, (2) half-strong form efficiency by testing market model (single index model) and Capital Assest Pricing Model (CAPM); and (3) efficiency and strong form with testing Capital Assets Pricing Model (CAPM) also is by analyzing the performance of a variety of professionally managed portfolios such as mutual funds.
\end{abstract}

Keywords: capital market efficiency (weak form, semi strong form, strong form 


\section{PENDAHULUAN}

Pemodal yang ingin melakukan investasi, maka investasi bisa dilakukan pada aktiva riil atau real assets (membangun pabrik, membuat produk baru, menambah saluran distribusi, dan sebagainya), ataupun pada aktiva finansial (financial assets), atau sekuritas (membeli sertifikat deposito, commercial paper, saham, obligasi atau sertifikat reksadana). Investasi yang terakhir merupakan bagian dari investasi di pasar modal.

Pasar modal secara formal dapat didefinisikan sebagai pasar untuk berbagai instrumen keuangan (atau sekuritas) jangka panjang yang bisa diperjualbelikan, baik dalam bentuk hutang ataupun modal sendiri, baik yang diterbitkan oleh pemerintah, public authoritie, maupun perusahaan swasta. Dengan demikian, pasar modal merupakan konsep yang lebih sempit, dari pasar keuangan (financial market). Dalam financial market, diperdagangkan semua bentuk hutang dan modal sendiri, baik dana jangka pendek maupun jangka panjang, baik negotiable ataupun tidak (Kasmir, 1998).

Pasar modal diminati di banyak negara karena pasar modal menjalankan fungsi ekonomi dan keuangan. Fungsi ekonomi artinya pasar modal menyediakan fasilitas untuk memindahkan dana dari lender ke borrower. Sedangkan fungsi keuangan dilakukan dengan menyediakan dana yang diperlukan oleh para borrowers dan para lenders menyediakan dana tanpa harus terlibat langsung dalam kepemilikian aktiva riil yang diperlukan untuk investasi tersebut. Pasar modal diharapkan bisa menjadi alternatif penghimpunan dana selain sistem perbankan. Disamping itu, pasar modal memungkinkan para pemodal mempunyai berbagai pilihan investasi yang sesuai dengan preferensi resiko mereka. Dengan adanya pasar modal, para pemodal memungkinkan untuk melakukan diversifikasi investasi, membentuk portofolio (gabungan dari berbagai investasi) sesuai dengan resiko yang mereka bersedia tanggung dan tingkat keuntungan yang mereka harapkan. Dalam kaitan dengan hal ini, maka dalam keadaan pasar modal yang efisien, hubungan yang positif antara risiko dan keuntungan yang diharapkan akan terjadi (Husnan, $2009: 5$ )

\section{PEMBAHASAN}

Secara formal, pasar modal yang efisien didefinisikan sebagai pasar yang harga sekuritas-sekuritasnya telah mencerminkan semua informasi yang relevan (Husnan, 2009 : 260). Semakin cepat informasi baku tercermin dari harga sekuritas, semakin efisien pasar modal tersebut.

Weston dan Copeland (1997 : 107) mendefinisikan pasar modal yang efisien sebagai berikut: "A security market is said to be efficient if the price instancously and fully refflects all relevant available information." Sedangkan Fama (1970, dalam Jogiyanto, 2008 : 503) mendefinisikan pasar yang efisien adalah "suatu pasar sekuritas dikatakan efisien jika harga-harga sekuritas mencerminkan secara penuh informasi yang tersedia."

Jadi, semua informasi yang diketahui bukan saja mengacu kepada informasi yang lalu, tetapi juga informasi saat ini yang diterima oleh orang umum (seperti laporan keuangan, dividen, dan pecahan saham).

Menurut Fahmi dan Yovi Lavianti Hadi (2009 : 83), bahwa syarat-syarat umum yang harus dipenuhi bagi terciptanya suatu pasar modal yang efisien adalah sebagai berikut .

\section{a. Disclousure \\ Disclousure adalah berbagai} informasi pengetahuan dan perkiraan direfleksikan atau tergambarkan secara akurat dalam harga-harga pasar tersebut, dimana berbagai pihak mengetahui sebab musabab naik turunnya harga tersebut dari berbagai perolehan informasi baik dari sisi fundamental dan teknikal analisis. Dan data-data tersebut dapat diperoleh tanpa ada batas dan biaya dengan waktu yang cepat akurat serta dapat dipertanggungjawabkan kebenarannya.

b. Pasar dalam keadaan seimbang

Pasar berada dalam keadaan seimbang seperti usaha-usaha untuk memasukkan informasi baru. Dengan 
demikian, terserapnya informasi baru terebut ke pasaran akan menghasilkan nilai instrinsik saham. Kondisi pasar yang seimbang, memungkinkan terciptanya equilibrium pasar (EqP).

c. Kondisi pasar berlangsung secara bebas

Kondisi pasar berlangsung secara bebas adalah dimana tidak ada seorangpun yang bisa mempengaruhi kondisi harga di pasar, berbagai pihak memperoleh informasi yang sama, dan tidak ada saling interverensi.

Sedangkan Ahmad Rodomi dan Otherman Yong (2002) berpendapat ada beberapa syarat yang harus dipenuhi untuk terciptanya pasar modal yang efisien sebagai berikut :

a. Harga saham harus bebas untuk turun dan naik. Hal ini berarti tidak ada seorang pun yang dapat mempengaruhi pergerakan harga saham.

b. Tidak ada monopoli dalam pasar. Hal ini berarti para investor bebas untuk masuk atau keluar dari pasar.

c. Harus ada syarat menghendaki perusahaan yang menyingkapkan informasi tentang dirinya. Peraturan harus diadakan supaya setiap perusahaan menyingkapkan informasi masing-masing kepada orang banyak.

d. Biaya untuk mendapatkan informasi adalah pada tahap minimum dan informasi itu harus diterima oleh investor pada waktu yang sama.

e. Informasi tersebut adalah dalam bentuk random dan tidak bergantung antara satu sama lain.

f. Investor-investor bertindak cepat terhadap informasi baru.

Bentuk pasar modal yang efisien berkaitan dengan semua informasi yang relevan. Fama (1970) mengklasifikasikan informasi menjadi tiga tipe, yaitu (1) perubahan harga di waktu lalu (past price changes); (2) informasi yang tersedia kepada publik (public information); dan (3) informasi tersedia baik kepada publik maupun tidak (public and private information). Oleh karena itu, ada tiga bentuk pasar modal yang efisien, yaitu :
(1) efisiensi bentuk yang lemah (weak form efficiency); (2) efisiensi bentuk setengah kuat (semi strong form efficiency); dan (3) efisiensi bentuk kuat (strong form efficiency).

Pasar modal yang efisien dalam bentuk lemah (weak form) menyatakan bahwa keadaan dimana harga saham mencerminkan semua informasi yang ada pada catatan harga di waktu lalu. Dalam keadaan seperti ini, berarti tidak seorang investor pun mendapat keuntungan di atas normal (abnormal return), dengan mempelajari gerakan harga-harga sekuritas historis untuk memprediksi gerakan dan arah harga sekuritas pada periode yang akan datang. Karena gerakan harga sekuritas tersebut bersifat acak (random walk), sehingga sangat sulit memprediksi arah perubahan harga periode yang akan datang.

Pasar modal yang efisien dalam bentuk setengah kuat (semi strong form) menyatakan bahwa keadaan dimana harga-harga bukan hanya mencerminkan harga-harga di waktu yang lalu, tetapi semua informasi yang dipublikasikan. Informasi publik akan tercermin ke dalam harga saham secara cepat dan tidak bias. Hal ini berarti para investor tidak akan dapat memperoleh keuntungan di atas normal (abnormal return), dengan membeli saham atas adar suatu publikasi.

Pasar modal yang efisien dalam bentuk kuat (strong form) menyatakan bahwa semua informasi yang relevan yang tersedia tercermin dalam harga saham. Jadi, baik informasi yang telah dipublikasikan maupun yang belum dipublikasikan (private information) akan tercermin dalam harga saham. Dalam keadaan seperti ini tidak seorang investor pun dapat memperoleh abnormal return (excess return) dengan menggunakan informasi apapun. Modal

Pengujian Terhadap Efisiensi Pasar

a. Untuk menguji apakah pasar modal yang efisien dalam bentuk yang paling lemah, dipergunakan antara lain pengujian koefisien korelasi perubahan harga saham untuk time lag tertentu. Pasar modal efisien

I Nyoman Sujana | 35 dari 69 
dalam bentuk lemah berarti perubahan harga saham di waktu yang lalu tidak bisa dipergunakan untuk memperkirakan perubahan harga di masa yang akan datang. Oleh karena itu, perlu diamati korelasi perubahan harga di waktu yang lalu dengan perubahan harga di masa yang akan datang. Apabila $P t$ adalah harga pada waktu $t$, maka perubahan harga tersebut akan sesuai dengan persamaan :

$$
P_{t}-P_{t-1}=a+b\left(P_{t-1-T}-P_{t-2-T}\right)+e_{t}
$$

Parameter a menunjukkan perubahan harga yang tidak berkorelasi dengan perubahan di waktu lalu. Karena sebagian besar saham mempunyai tingkat keuntungan yang positif, maka a seharusnya positif. Parameter $b$ menunjukkan hubungan antara perubahan harga di waktu yang lalu dengan perubahan harga di masa yang akan datang. Apabila $T=0$, maka persamaan tersebut menunjukkan hubungan antara perubahan harga yang akan datang dengan perubahan harga yang terakhir. Apabila $T=1$, maka ini berarti hubungan antara perubahan harga yang akan datang dengan perubahan harga dua periode sebelumnya. Sedangkan parameter $e$ merupakan angka random, termasuk dalam variabilitas perubahan harga saat ini dan tidak berkorelasi dengan perubahan harga yang lalu. Diharapkan nilai $b$ tidak berbeda dengan nol, yang berarti bahwa tidak ada hubungan antara perubahan harga yang lalu dengan perubahan harga yang akan datang.

Pengujian efisiensi bentuk lemah umumnya terbukti apabila dipergunakan uji filter rules. Uji filter rules berarti kita mencoba membuat trading rules tertentu, dan kemudian kita bandingkan tingkat keuntungan yang diperoleh berdasarkan atas rules tersebut dan hasil seandainya kita beli dan simpan secara sembarang. Trading rules yang dipergunakan biasanya dinyatakan sebagai berikut : "Beli saham pada saat harganya telah turun dengan y\%." Asumsi yang dipergunakan adalah bahwa setelah saham mengalami kenaikan akan diikuti kenaikan lagi, demikian pula dengan apabila terjadi penurunan. Penelitian Fama (1970) menunjukkan umumnya strategi filter rules tidak memberikan hasil yang lebih baik dibandingkan dengan beli dan simpan secara sembarang, lebihlebih kalau diperhatikan adanya biaya transaksi.

b. Pengujian tentang bentuk efisiensi setengah kuat ditujukan apakah harga benar-benar mencerminkan informasi yang dipublikasikan. Hipotesa yang dipergunakan adalah bahwa segera setelah suatu informasi menjadi milik publik, pemodal tidak bisa memperoleh abnormal returns. Abnormal returns adalah selisih antara tingkat keuntungan sebenarnya dengan tingkat keuntungan yang diharapkan. Tingkat keuntungan yang diharapkan dihasilkan dengan menggunakan model tertentu. Model yang paling sering dipergunakan adalah market model (atau single index model dan Capital Asset Pricing Model (CAPM), misalkan dipergunakan market model yang secara umum dinyatakan sebagai berikut :

$$
E\left(R_{1}\right)=\alpha_{1}+\beta_{1} R_{m}+e_{1}
$$

Dengan demikian diperlukan data tingkat keuntungan portofolio pasar (yang biasa diwakili oleh indeks pasar) dan tingkat keuntungan saham $i$ (saham yang diamati). Kemudian kita regresikan tingkat keuntungan saham terhadap tingkat keuntungan portofolio pasar. Misalkan dari regresi tesebut kita peroleh persamaan sebagai berikut .

$$
E\left(R_{1}\right)=0,008+1,2\left(R_{m}\right)
$$

Sekarang misalkan kita melakukan pengamatan selama tiga bulan terhadap tingkat keuntungan saham 
$i$ yang telah diperoleh data tingkat keuntungan portofolio pasar.

Datanya adalah sebagai berikut, data disajikan pada table 1 .

Tabel 1. Keuntungan portofolio pasar

\begin{tabular}{cccc}
\hline Bulan & $\mathrm{R}_{\mathrm{m}}$ & $\mathrm{R}_{\mathrm{i}}$ & $\mathrm{E}\left(\mathrm{R}_{\mathrm{i}}\right)$ \\
\hline 1. & 0,021 & 0,025 & $0,008+1,2(0,021)=0,0332$ \\
2. & 0,012 & 0,028 & $0,008+1,2(0,012)=0,0224$ \\
3. & 0,030 & 0,035 & $0,008+1,2(0,030)=0,0440$ \\
\hline
\end{tabular}

Dengan demikian bisa dihitung abnormal returns (yaitu $\mathrm{R}_{\mathrm{i}}-$

Abnormal returns $1=0,025-0,0332$

Abnormal returns $2=0,028-0,0224$

Abnormal returns $3=0,035-0,044$
$E\left(R_{i}\right)$ selama tiga bulan tersebut.

$$
\begin{aligned}
& =-0,0082 \\
& =+0,0056 \\
& =-0,009
\end{aligned}
$$

Jadi : selama tiga bulan tersebut nampak bahwa hanya pada bulan kedua diperoleh abnormal returns (AR) yang positif. Artinya, tingkat keuntungan yang diperoleh lebih tinggi dari yang diharapkan yang ditaksir dengan market model, sedangkan pada bulan-bulan lainnya diperoleh abnormal returns yang negatif. Dalam kaitan ini, sering juga dihitung Cumulative Abnormal Returns (CAR), yang tidak lain merupakan penjumlahan $A R$ dari periode ke periode, untuk melihat perkembangan abnormal returns selama beberapa periode. Apabila kita terapkan pada data di atas, maka CAR saham tersebut selama tiga bulan tersebut adalah sebagai berikut .

$$
\begin{array}{ll}
\mathrm{CAR}_{1} & =-0,0082 \\
\mathrm{CAR}_{2} & =-0,0026 \\
\mathrm{CAR}_{3} & =-0,0116
\end{array}
$$

Husnan dan Hanafi (1991) meneliti perilaku harga saham di pasar perdana di Bursa Efek Jakarta pada tahun 1990.. setelah saham-saham tersebut diperdagangkan di bursa, minggu pertama memang menunjukkan bahwa pemodal mampu memperoleh rata-rata abnormal return (AR) yang positif dan signifikan. Tetapi setelah masuk ke pasar sekunder, terjadi kenaikan harga saham-saham (relatif terhadap pasar), dan sewaktu mencapai minggu ke-4 kenaikan itu telah demikian tingginya sehingga terjadi rata-rata $A R$ yang negatif berarti harga saham sudah terlalu tinggi. Fenomena tersebut juga menunjukkan bahwa efisiensi informasi pasar modal dalam bentuk setengah kuat masih belum terpenuhi.

c. Pengujian tentang efisiensi bentuk kuat (strong firm) dilakukan terhadap hipotesa yang menyatakan bahwa harga saham tidak hanya mencerminkan semua informasi yang dipublikasikan, tetapi juga informasi yang mungkin tidak diketahui umum. Beberapa kelompok mempunyai kemampuan untuk memperoleh informasi yang pihak umum tidak bisa memperolehnya. Demikian juga ada pihak-pihak yang menyatakan bahwa mereka bisa melakukan analisa fundamental sehingga bisa memperoleh informasi yang lebih dalam daripada apa yang dipublikasikan. Pengujian terhadap hipotesa ini dilakukan dengan cara menganalisa prestasi berbagai portofolio yang dikelola oleh kelompok-kelompok yang mungkin mempunyai informasi khusus. Berbagai portofolio yang dikelola secara profesional dicoba dianalisa 
prestasinya apakah bisa memberikan keuntungan yang lebih besar daripada pasar secara keseluruhan. Apabila hal ini berlangsung terus menerus, maka dikatakan bahwa pasar modal tidak dalam keadaan efisien. Portofolioportofolio yang dikelola secara profesional antara lain adalah mutual funds. Investor yang membeli mutual funds pada hakekatnya membeli beberapa jenis saham, karena setiap mutual funds mewakili jenis saham. Studi yang dilakukan oleh Irwin Frieud, et.al. (1958) terhadap 189 mutual funds selama periode Desember 1952 sampai dengan September 1958, menunjukkan bahwa rata-rata prestasi mutual funds tidaklah banyak berbeda dengan prestasi portofolio-portofolio yang tidak dikelola secara profesional dengan komposisi aktiva yang serupa. Tingkat keuntungan portofolio-portofolio yang tidak dikelola secara profesional diwakili oleh standard 2 Poor's Indexes. Kira-kira setengah dari mutual funds tersebut berprestasi lebih baik, tetapi setengahnya lagi ternyata berprestasi lebih buruk daripada tingkat keuntungan standard 2 poor's stocks. Tidak ada bukti bahwa mutual funds tersebut selalu baik daripada portofolio yang dikelola dengan tidak profesional.

Pendekatan yang digunakan adalah Capital Assets Pricing Model (CAPM). Dalam model ini ternyata sebagian mutual funds tersebut memang memperoleh tingkat keuntungan di atas Security Market Line, sebagian juga berada di bawah garis tersebut. Dengan demikian, dapat disimpulkan bahwa funds tersebut tidak memberikan hasil yang selalu konsisten melebihi prestasi pasar pada umumnya dan bisa dikatakan dalam bentuk yang kuat (strong form), pasar modal juga efisien. Dokumentasi yanf dilakukan oleh Elton dan Gruber (1991) menunjukkan bahwa saran para analis finansial yang dilakukan secara serempak memungkinkan pemodal memperoleh abnormal returns yang positif. Yang menjadi masalah adalah pada biaya transaksi. Kalau biaya transaksi dimasukkan yang bisa menjadi besar karena menggunakan jasa analis keuangan yang cukup banyak, abnormal returns yang positif menjadi tidak signifikan.

\section{SIMPULAN}

Berdasarkan uraian di atas, maka dapat disimpulkan hal-hal sebagai berikut .

1. Pasar modal yang efisiensi adalah pasar modal yang harga sekuritassekuritasnya mencerminkan semua informasi yang relevan. Informasi menyangkut : (1) perubahan harga di waktu yang lalu (past price changes); (2) informasi yang tersedia kepada publik (public information), dan (3) informasi yang tersedia baik kepada publik maupun tidak (public and private information).

2. Syarat-syarat yang harus dipenuhi bagi terciptanya suatu pasar modal yang efisien adalah : (1) disclousure artinya informasi tergambarkan secara akurat dalam harga pasar tersebut dan berbagai pihak mengetahui sebab - sebab naik turunnya harga tersebut baik dari sisi fundamental maupun teknikal analisis, (2) pasar dalam keadaan seimbang yang memungkinkan terciptanya equilibrium pasar, dan (3) kondisi pasar berlangsung secara bebas artinya tidak ada seorangpun yang bisa mempengaruhi kondisi harga di pasar, berbagai pihak memperoleh informasi yang sama, dan tidak ada slaing intervensi.

3. Bentuk-bentuk pasar modal yang efisien meliputi : (1) efisiensi bentuk lemah berarti bahwa para pemodal tidak bisa memperoleh abnormal returns dengan menggunakan informasi perubahan harga saham di waktu yang lalu, (2) efisiensi bentuk setengah kuat berarti para pemodal tidak bisa memperoleh abnormal 
returns dengan menggunakan informasi yang telah menjadi milik publik, dan (3) efisiensi bentuk kuat berarti para pemodal tidak bisa memperoleh abnormal returns baik dengan menggunakan informasi yang menjadi milik publik maupun tidak.

4. Pengujian terhadap efisiensi pasar modal adalah (1) efisiensi bentuk lemah dipergunakan pengujian koefisien korelasi perubahan harga saham untuk time lag tertentu, (2) efisiensi bentuk setengah kuat dipergunakan pengujian market model (single index model) dan Capital Assets Pricing Model (CAPM); dan (3) efisiensi bentuk kuat juga dipergunakan pengujian Capital Assets Pricing Model (CAPM), dengan cara menganalisa prestasi berbagai portofolio yang dikelola secara profesional seperti mutual funds yang mewakili beberapa jenis saham.

\section{DAFTAR PUSTAKA}

Brigham., Eugene, F., Daves, \& Philip, F. 2010. Intermediate Financial Management. 10 th Edition. Thomson South Western

Elton, E.J., \& Gruber, M.J. 1991. Modern Portofolio Theory and Investment Analysis, Jhon Wiley and Sons

Fahmi., Irham \& Hadi, Y.L. 2009. Teori Portofolio dan Analisis Investasi. Teori dan Soal Jawab. Bandung: Penerbit Erlangga

Fama, E.F. 1970. Efficient Capital Market : A Review of Theory and Empirical Works. Journal of Finance, May

Hanafi, Mahduh \& Husnan, S. 1991. Perilaku Harga Saham di Pasar Perdana : Pengamatan di Bursa Efek Jakarta selama 1990. Manajemen dan Usahawan Indonesia, Nopember

Husnan \& Suad. 2009. Dasar-dasar Teori Portofolio dan Analisis Sekuritas. Edisi Keempat. Yogyakarta : UPP STIM YKPN

Jogiyanto. 2008. Teori Portofolio dan Analisis Investasi. Yogyakarta : BPFE
Kasmir. 1998. Bank dan Lembaga Keuangan Lainnya. Jakarta : PT. Raja Grafindo Rosada

Rodomi, Ahmad \& Yong, O. 2002. Analisis Investasi dan Teori Portofolio. Jakarta : PT. Raja Grafindo Persada

Ross, Stephen A, Randolph W. Westerfield, Jeffrey Jaffe, and Bradford D. Jordan.2009. Modern Financial Management. Eighth Edition. Mc Graw-Hill International. New York

Weston, J. Fred dan Copeland, Thomas E. 1997. Manajemen Keuangan. Edisi Kesembilan. Alih Bahasa : A. Jaka Wasana dan Kibrandoko. Jakarta : Bina Rupa Aksara 
